\title{
Strategi Penanggulangan Praktek Rentenir
}

\author{
AFVAN AQUINO; IDEL WALDELMI; WITA DWIKA LISTIHANA
}

\author{
Universitas Lancang Kuning \\ Jln. Yos Sudarso Km 08 Rumbai Telp. (0761) 52581 Fax. (0761) 52581 \\ E-mail : idelwaldelmi@gmail.com
}

\begin{abstract}
This research was conducted in an effort to analyze and identify the external and internal factors of traders and strategies in overcoming the practices of moneylenders in the Islamic market ulul albab siak hulu Kampar. This study uses qualitative methods, carried out in natural settings with qualitative methods. The results showed that the implementation of aggressive strategies on the handling of rentenir practices in Islamic market traders ulul albab can be done using the SO strategy by utilizing the strength of the sharia market itself to seize the opportunities and to use the Sharia-compliant syariah market to support the application of the rentenir practice itself can be ended and immediately to establish / establish a sharia financial institution / BMT (Baitul mall wa tan will) / sharia cooperative.
\end{abstract}

Keywords: Rentenir, Market Traders, Managers, Government

\begin{abstract}
Fenomena pengusaha Usaha Kecil/Pedagang kecil/barang harian kelontong di pasar syariah ulul albab desa tanah merah kecamatan siak hulu Kampar memiliki cerita dan karakter pelaku usaha biasanya sulit menerima masukan dari orang lain dan tidak mau belajar untuk meningkatkan wawasan maupun kemampuan mereka dalam memajukan usaha.
\end{abstract}

Konsekuensi akan pentingnya kegiatan wirausaha, Islam menekankan pentingnya pembangunan dan penegakan budaya kewirausahaan dalam kehidupan setiap muslim. Budaya kewirausahaan muslim itu bersifat manusiawi dan religius, berbeda dengan budaya profesi lainnya yang tidak menjadikan pertimbangan agama sebagai landasan kerjanya. Seorang wirausahawan muslim akan memiliki sifatsifat dasar yang mendorongnya untuk menjadi pribadi yang kreatif dan handal dalam menjalankan usahanya, atau menjalankan aktivitas pada perusahaan tempatnya bekerja (Awaluddin, 2017).

Peminjaman kepada rentenir adalah peminjaman modal dari pemilik modal kepada pihak yang membutuhkan modal (biasanya transaksinya individu, masuk ruangan privasi dan door to door). Rentenir akan meminjamkan uangnya berapun yang dibutuhkan oleh nasabahnya, rentenir tidak melihat kepada usaha/bisnis yang dijalankan si nasabah, karena bagi rentenir itu tidak perlu, asal si nasabah bisa melunasi hutangnya sesuai waktu yang disepakati.

Menurut M. Ishak, tingginya kebutuhan masyarakat akan dana atau pembiayaan terutama untuk modal usaha, membuat rentenir masih akan tumbuh pesat di sepanjang tahun 2014. Selain karena mudah mencairkan dananya juga karena proses administrasi yang lebih mudah jika dibandingkan dengan mengajukan pembiayaan di perbankan (Simamora 2014). Rentenir dalam pandangan masyarakat Indonesia mempunyai stigma yang negatif, karena mengandung unsur bunga atau riba. Hal ini senada dengan yang disampaikan oleh Plato (427-347 SM) dalam bukunya Laws yang mengutuk bunga dan memandangnya sebagai praktik yang zalim. Dalam Islam, transaksi keuangan dengan sistem rente adalah salahsatu transaksi yang diharamkan.

Terlepas dari berbagai stigma negatif tersebut, jasa rentenir justru masih dibutuhkan oleh masyarakat terutama pedagang kecil yang membutuhkan modal untuk usaha yang digelutinya. Kelebihan 
meminjam dari rentenir adalah karena persyaratan yang mudah, kecepatan dalam pencairan dana, dan tidak adanya jaminan dalam bentuk apa pun. Keunggulan yang ditawarkan oleh rentenir menjadikan transaksi ini masih terus berkembang hingga sekarang dan membuat keberadaan lembaga keuangan lain seperti bank umum, bank swasta, termasuk lembaga keuangan syariah dan lembaga keuangan mikro secara total belum mampu menghilangkan keberadaan transaksi rente di Indonesia. Selain itu, praktik rentenir ini selalu menyasar kelompok masyarakat menengah ke bawah. Karena mereka adalah kelompok yang paling rentan disebabkan tingkat pendidikan serta kesulitan aksesibilitas mereka terhadap lembaga keuangan yang formal sehingga mudah diperdaya.

Utang piutang diperbolehkan dalam Islam karena termasuk sikap tolong menolong, namun demikian banyak diantara pemberi utang yang mengambil manfaat atau keuntungan dari orang yang berutang, misalnya praktik rentenir. Rentenir adalah orang yang mencari nafkah dengan membungakan uang, tukang riba, pelepas uang, lintah darat. Renten atau kegiatan renten merupakan suatu aktifitas dimana seseorang meminjamkan uang dengan bunga yang berlipat-lipat yang memungkinkan bunga tersebut melebihi utang pokoknya jika cicilannya terlambat. Rentenir mempunyai tujuan untuk membantu orang yang kurang mampu, tetapi di dalam praktiknya rentenir membungakan jumlah uang yang dipinjamkan sehingga menyimpang dari nilai kebaikan(Hidayah, 2018).

Masih diterimanya transaksi rente sebagai solusi permodalan oleh pedagang di pasar tradisional apalagi pasar yang berbasis syariah yakni seperti pasar syariah ulul albab, dimana merebaknya para penawar jasa keuangan pasar ini, haruslah menjadi perhatian semua pihak khususnya pengelola pasar. Pembiayaan permodalan melalui jasa rentenir ini hanyalah memberikan solusi untuk jangka pendek. Modal memang mudah didapat, tapi dalam jangka panjang pedagang dihadapkan pada bunga yang tinggi dari pinjaman dan akan menjerat kondisi keuangan mereka(sabirin dan dini ayuning, 2017). (Surahma Asti Mulasari, Ana Nur Fatihah, 2018)Buruknya dampak rentenir dapat diatasi oleh keberadaan lembaga keuangan formal seperti halnya koperasi atau BMT. Lembagai keuangan seperti BMT dapat memberikan bantuan solusi dana yang mudah dan cepat terhadap masyarakat ekonomi kelas bawah agar tidak terjerat oleh rentenir (Yunadi, 2011).

Sesuai dengan fenomena yang dijabarkan di atas, akan menjadi sangat penting untuk dicarikan solusi alternative bagi pedagang di pasar syariah ulul albab dan bagi lembaga keuangan mikro syariah untuk memperluas jangkauan mereka dengan melakukan upaya penjemputan bola, melalui beberapa hal seperti meringankan kerumitan administrasi yang selama ini masih menjadi kendala. Lembaga keuangan mikro syariah harus mampu menyasar para pelaku usaha mikro, kecil, dan menengah, khususnya para pedagang di pasar tradisional yang membutuhkan sumber permodalan dalam melakukan aktivitas perdagangan atau usaha mereka.

Berdasarkan dari urgensi latar belakang permasalahan yang telah dijabarkan, maka tujuan penelitian ini untuk identifiasi factor inter dan eksternal pedagang pasar syariah dan strategi yang bisa dilakukan untuk penanggulan praktek rentenir di pasar syariah ini dan Penelitian ini akan membahas tentang Strategi Penanggulangan Praktek Rentenir Di Pasar Syariah Ulul Albab yang berdasarkan pada prinsip-prinip syariah.

Syariah dalam perspektif teologis merupakan sekumpulan perangkat peraturan tentang ajaran yang digunakan untuk mengawal kehidupan manusia ke arah yang lebih baik, maju dan dinamis berdasarkan nilai-nilai ketuhanan (nilai Islam). Berdasarkan hal tersebut, syariah mengandung berbagai syari'at, dan syariat 
itu adalah ajaran, maksudnya ajaran Islam. Dengan kata lain syariah adalah dengan Islam. Ketika disebut syariah, maka berarti Islam, dan manakala dikatakan Islam, maksudnya adalah syariah. Islam bagaikan badannya sementara syariah bagaikan batinnya, yakni ajarannya. Salah satu ajaran dalam Islam adalah kewajiban kasab, ikhtiar dan usaha mencari karunia Allah Swt (rezeki) yang halal dan banyak untuk bekal hidup di dunia menuju akhirat. Sebagai bentuk manifesatasi dari kasab itu adalah bisnis. Bisnis yang dijalankan seyogyanya bisnis yang halal dan menghalalkan serta diridhai Allah Swt. Bisnis yang seperti itu tiada lain adalah bisnis syariah, bisnis yang dilakukan, dijalnkan dan dikembangkan sejalan, senafas dengan nilai, watak, karakter dan prinsip-prinsip transendental Islam.

Paraktek bisnis syariah maupun kajian konsepsional telah banyak dilakukan oleh berbagai kalangan dan para ahli ekonomi dengan berbagai latar belakang pendidikan dan pengalaman. Mereka berlomba-lomba menunjukan kemampuan dan keahliannya. Hal ini sah dan dinilai baik, jika dilakukan semata karena li i'lali kalimatilah. Namun demikian belum banyak yang melakukannya menuju pada tahapan-tahapan menuju idealisme tersebut.

Kinerja ekonomi syariah tidak hanya dilakukan oleh masyarakat zaman sekarang, namun telah berjalan dan bergerak langkah-langkah ekonomi syariah dari sejak dulu. Tentu saja hal ini dilakukan oleh para Sahabat dan tabiin setelah mereka mendapat teladan dan petunjuk dari imam besarnya, yakni Nabi Muhamad Saw. Beliau adalah sosok terpercaya, terhebat, serta sangat piawai dan ahli dalam berbisnis. Tidak diragukan lagi Nabi Muhammad Saw. adalah penggiat pertama sekaligus bapak ekonomi syariah di dunia ini yang membawa rahmat dan berkah kepada seluruh alam.

Islam telah mengajarkan melalui Nabi Muhammad SAW tentang konsep konsep marketing yang islami secara lengkap,yang tidak mungkin bisa diungkapkan secara keseluruhan karena penulis bukanlah ahlinya. Namun tidak ada salahnya penuls coba telusuri sesuai kemampuan yang ada mudah udahan saja pembaca bisa memakluminya. Dalam pemasaran (marketing) konsep paling utama adalah kejujuran, supaya para pelanggan tetap setia memamfaatkan jasa atau sesuatu produk yang dikeluarkan oleh perusahaan atau individu yang pada gilirannya akan mendatangkan keuntungan .Kesetiaan itu tercipta jika ada kepercayaan ,yang lahir dari hubungan yang baik karena didasarkan oleh sikap yang saling percaya. Dan sikap sikap saling percaya tersebut akan terbentuk dan tumbuh apabila kedua pihak dalam hal ini adalah pihak perusahaan atau para penjual dengan pelanggan atau pihak pembeli sama sama jujur.Jika sebaliknya,atau tidak jujur mustahil dan tidak mungkin mengharapkan kesetiaan konsumen .Karenanya,kejujuran sangat menentukan maju tidaknya sesuatu perusahan .Berpijak dari itu,maka kejujuran tersebut tidak hanya ditujukan kepada konsumennya saja,tetapi juga kejujuran ditujukan pula kepada distributor, penanam modal (investor) dan juga masyarakat secara keseluruhannya. Dan soal kejujuran tersebut sampai kini hanya Nabi SAW saja yang paling jujur dan bisa dipercaya sehingga beliau dijuluki $\mathrm{Al}$ Amin. Marketing yang dilakoni oleh Nabi Muhammad SAW pada abad ketujuh Masehi tersebut dilandasi oleh sikap kejujuran,ikhlas, profesionalisme, silaturrahmi,dan murah hati.

Rentenir secara harafiah berasal dari kata Rente yang artinya renten, bunga uang. Kata ini tidak jauh berbeda dengan makna Riba yang secara bahasa berarti Ziyadah (tambahan) baik dalam transaksi jual beli maupun pinjam meminjam. Institusi yang memperoleh profit melalui penarikan bunga disebut sebagai lembaga rente, seperti Bank, koperasi dan lembaga perkreditan lainnya. Sedangkan individu 
yang memperoleh provit melalui penarikan bunga disebut dengan rentenir.

Bila ditinjau dari segi fiqih, menurut Qardhawi bunga bank sama dengan riba yang hukumnya jelas-jelas haram. Suatu sistem ekonomi Islam harus bebas dari bunga (riba). Hanya sistem ekonomi islam yang dapat menggunakan modal dengan benar dan baik, karena dalam sistem ekonomi kapitalis dijumpai bahwa manfaat keuntungan teknik yang dicapai oleh ilmu pengetahuan hanya bisa dinikmati oleh segelintir orang saja Begitu banyak malapetaka yang melanda umat manusia masa kini, khususnya dalam bidang ekonomi.

Dampak negatif rentenir terhadap keberlangsungan hidup masyarakat yakni Dampak Ekonomi di antara dampak ekonomi riba adalah dampak inflatoir yang diakibatkan oleh bunga sebagai biaya uang. Hal tersebut disebabkan karena salah satu elemen dari penentuan harga adalah suku bunga. Semakin tinggi suku bunga, semakin tinggi juga harga yang akan ditetapkan dalam suatu barang.

Berdasarkan hasil penelitian yang dilakukan oleh (Khairi, 2018) maka dapat ditarik kesimpulan bahwa alasan pedagang adalah dikarenakan proses peminjaman uang yang cepat, mudah, tidak harus memiliki barang berharga sebagai jaminan, nominal pinjaman tidak terlalu besar, hanya bermodalkan kepercayaan, dapat langsung menerima pinjaman uang dan karena keterpaksaan. Permasalahan kedua dampak pinjaman rentenir terhadap pendapatan dan pedagang yaitu sebagian pedagang ada yang menyatakan bahwa pendapatan mereka sama seperti biasa sebagian pedagang lain menyatakan pendapatan mereka semakin hari semakin menurun yang disebabkan oleh kewajiban mereja atas pembayaran pinjaman uang kepada rentenir yang setiap hari dilakukan. Pedagang harus membayar bunga dari pinjaman mereka. Itulah sebabnya pendapatan mereka semakin lama semakin menurun.
(Tunerah, 2015) dimana Hasil perhitungan product moment diperoleh nilai 0,439 yang berada diantara 0,40 0,599 berarti mempunyai memiliki pengaruh yang sedang dan hasil perhitungan uji determinasi diketahui nilai koefisien determinasi sebesar 0,192 (19\%). Hal ini menunjukan bahwa kredit rentenir memberikan pengaruh terhadap penurunan kesejahteraan masyarakat sebesar $19 \%$, melalui persamaan regresi $\hat{Y}$ $=1,247+0,207 \mathrm{X}$, sedangkan sisanya yaitu $81 \%$ dipengaruhi oleh faktor lain. Sehingga hipotesis yang diajukan yaitu Ha diterima dan Ho ditolak. Artinya terdapat pengaruh yang signifikan antara jasa kredit rentenir terhadap tingkat kesejahteraan masyarakat.

(SIBORO, 2015) Retenir pada dasarnya bekerja untuk memperoleh keuntungan dari bunga yang mereka berikan kepada nasabah, berbeda dengan peminjaman karena niat ingin membantu seseorang yang sedang dalam kesulitan, biasanya mereka tanpa memberikan bunga ataupun jaminan karena peminjaman tipe ini, bukanlah peminjaman system rentenir tapi peminjaman karena adanya hubungan kekerabatan ataupun keluarga. Pekerjaan rentenir pada dasarnya sudah melanggar semua nilai-nilai agama. Karena dalam agama apapun kegiatan rentenir atau membungakan uang adalah hal yg dilarang dalam agama, berbeda dengan nilai hukum di Indonesia, kegiatan rentenir tidak ada pasal-pasal yang melarang kegiatan tersebut. Karena hampir semua lembaga peminjaman di Indonesia.

(Syafrini, 2014)Rentenir yang ada di sekeliling nelayan merupakan ancaman bagi kehidupan dan masa depan mereka, tapi apa yang harus mereka lakukan jika jeratan itu semakin kuat sementara jalan terang untuk keluar tidak kunjung ditemukan? Walaupun sebenarnya rentenir pada dasarnya masih memiliki sisi positif dalam kehidupan masyarakat, tetap saja praktek rentenir bukan sesuatu yang harus dilegalkan. Rentenir harus 
tetap dimusnahkan, meskipun kita menyadari bahwa untuk memutus mata rantai ini tentu bukan perkara yang mudah, tapi tetap saja ia akan tetap jadi permasalahan besar bagi kehidupan nelayan jika masalah ini tidak segera diatasi. Sudah saatnya untuk memutus mata rantai ini nelayan sendiri yang harus dilibatkan, dengan mendirikan program ekonomi simpan pinjam berbasis mikro yang langsung disesuaikan dengan budaya setempat, program tersebut disesuaikan dengan adat istiadat dan budaya masyarakat, perberdayaan yang berbasis kearifan lokal. Jika nelayan telah terbiasa dan merasakan pro?it yang didapatkan maka rentenir secara lambat laun akan dilupakan, sehingga mata rantainya akan lapuk dan terputus secara perlahan. Jadi menghilangkan rintenir bukanlah sebuah kemustahilan, tapi sesuatu yang harus diupayakan.

(sabirin dan dini ayuning, 2017) Para pedagang hendaknya lebih menyadari kerugian yang akan mereka tanggung jika memilih rentenir sebagai sumber permodalan mereka. Walaupun rentenir memberikan kemudahan dalam peminjaman uang, tapi suku bunga tinggi yang harus mereka tanggung justru akan membuat mereka kesulitan dalam mendapatkan keuntungan.

\section{METODE}

Desain penelitian ini menggunakan metode kualitatif, Dilakukan dalam situasi yang wajar (natural setting) dengan Metode kualitatif peneliti berusaha memahami dan menafsirkan makna suatu peristiwa interaksi tingkah laku manusia dalam situasi tertentu menurut perspektif peneliti sendiri. Penelitian yang menggunakan penelitian kualitatif bertujuan untuk memahami obyek yang diteliti secara mendalam Bertujuan untuk mengembangkan konsep sensitivitas pada masalah yang dihadapi, menerangkan realitas yang berkaitan dengan penelusuran teori dari bawah (grounded theory) dan mengembangkan pemahaman akan satu atau lebih dari fenomena yang dihadapi dan teknik pengumpulan data dengan wawancara, observasi serta Dokumen lainnya yang mendukung hasil penelitian.

\section{HASIL}

Berdasarkan hasil penelitian yang berkaitan tentang Strategi Penanggulangan Praktek Rentenir di Pasar Syariah Ulul Albab : pertama tama yang dilakukan yakni melakukan analisis factor internal (IFAS) internal factor analisis yang terdiri dari factor kekuatan dan kelemahan yang dimiliki oleh pelaku usaha/dagang di pasar syariah.

Factor kekuatan yang merupakan dimensi dimensi yang terdapat Bagaimana Penerapan system syariah dipasar syariah, Bagaimana fungsi dewan syariah di pasar syariah, Bagaimana lembaga keuangan yang menopang permodalan pedagang pada pasar syariah, Bagaimana pengetahuan pedagang terhadap transaksi syariah dan Bagaimana ketaatan pedagang dalam menjalankan syariah. Untuk dapat lebih jelasnya dapat di lihat pada skor masing masing factor kekuatan dan dapat dilihatpada table berikut :

Tabel 1: Faktor Kekuatan

\begin{tabular}{|c|l|c|c|c|}
\hline Kekuatan & \multicolumn{1}{|c|}{ Keterangan } & Nilai & Bobot & $\mathbf{N x ~ B ~}$ \\
\hline 1 & $\begin{array}{l}\text { Bagaimana Penerapan system syariah } \\
\text { dipasar syariah }\end{array}$ & 3 & 0,2 & 0,6 \\
\hline 2 & $\begin{array}{l}\text { Bagaimana fungsi dewan syariah di } \\
\text { pasar syariah }\end{array}$ & 3 & 0,15 & 0,45 \\
\hline 3 & $\begin{array}{l}\text { Bagaimana lembaga keuangan yang } \\
\text { menopang permodalan pedagang pada } \\
\text { pasar syariah }\end{array}$ & 2 & 0,11 & 0,22 \\
\hline 4 & $\begin{array}{l}\text { Bagaimana pengetahuan pedagang } \\
\text { terhadap transaksi syariah }\end{array}$ & 2,66 & 0,1 & 0,266 \\
\hline 5 & $\begin{array}{l}\text { Bagaimana ketaatan pedagang dalam } \\
\text { menjalankan syariah }\end{array}$ & 3 & 0,1 & 0,3 \\
\hline & & & & 1,836 \\
\hline
\end{tabular}

Selanjutnya pada factor kelemahan merupakan dimensi - dimensi yang terdapat pada Bagaimana penggunaan modal riba, Bagaimana penetapan harga oleh pedagang, Bagaimana akad yang digunakan dalam bertransaksi, dan Bagaimana sanksi yang di terapkan. Untuk dapat lebih jelasnya skor masing -masing factor kelemahan dapat dilihat pada table berikut : 
Tabel 2 : Faktror Kelemahan

\begin{tabular}{|c|l|c|c|c|}
\hline Kelemahan & \multicolumn{1}{|c|}{ Keterangan } & Nilai & Bobot & N x B \\
\hline 1 & Bagaimana penggunaan modal riba & 1,07 & 0,11 & 0,1177 \\
\hline 2 & Bagaimana penetapan harga oleh pedagang & 2,98 & 0,08 & 0,2384 \\
\hline 3 & $\begin{array}{l}\text { Bagaimana akad yang digunakan dalam } \\
\text { bertransksi }\end{array}$ & 3 & 0,1 & 0,3 \\
\hline 4 & Bagaiamna sanksi yang di terapkan & 3 & 0,05 & 0,15 \\
\hline & & & 1 & 0,8061 \\
\hline
\end{tabular}

Selanjutnya berdasarkan hasil penelitian yang berkaitan tentang Strategi Penanggulangan Praktek Rentenir di Pasar Syariah Ulul Albab : pertama tama yang dilakukan yakni melakukan analisis factor eksternal (EFAS) internal factor analisis yang terdiri dari factor Peluang dan Ancaman yang dimiliki oleh pengelola/dewan syariah pasar di pasar syariah ulul albab.

Pada factor peluang yang merupakan dimensi - dimensi yang terdapat pada Bagaimana dukungan pemerintah terhadap keberadaan pasar syariah, Bagaimana respon masyarakat terhadap keberadaan pasar syariah, Bagaimana sikap dan kebijakkan pemerintah dalam mengembangkan pasar syariah, Bagaimana kondisi lingkungandisekitar pasar syariah dan Bagaimana keunggulan pasar syariah di bangdingkan pasar yang lain. Untuk lebih jelasnya skor masing -masing peluang dapat dilihat pada table berikut :

Tabel 3 : Faktor Peluang

\begin{tabular}{|c|l|c|c|c|}
\hline Peluang & \multicolumn{1}{|c|}{ Keterangan } & Nilai & Bobot & N x B \\
\hline 1 & $\begin{array}{l}\text { Bagaimana dukungan pemerintah terhadap } \\
\text { keberadaan pasar syariah }\end{array}$ & 2,66 & 0,18 & 0,4788 \\
\hline 2 & $\begin{array}{l}\text { Bagaimana respon masyarakat terhadap } \\
\text { keberadaan pasar syariah }\end{array}$ & 2,66 & 0,15 & 0,399 \\
\hline 3 & $\begin{array}{l}\text { Bagaimana sikap dan kebijakkan pemerintah } \\
\text { dalam mengembangkan pasar syariah }\end{array}$ & 2,66 & 0,05 & 0,133 \\
\hline 4 & $\begin{array}{l}\text { Bagaimana kondisi lingkungandisekitar pasar } \\
\text { syariah }\end{array}$ & 3 & 0,05 & 0,15 \\
\hline 5 & $\begin{array}{l}\text { Bagaimana keunggulan pasar syariah di } \\
\text { bangdingkan pasar yang lain }\end{array}$ & 2,67 & 0,075 & 0,20025 \\
\hline & \multicolumn{2}{|l|}{} \\
Sumber : Data Olahan 2019 & & & 1,36105 \\
\hline
\end{tabular}

Selanjutnya pada factor ancaman yang merupakan dimensi - dimensi yang terdapatkan pada Bagaimana tawaran pinjaman perbankan konvensional pada pedagang pasar syariah, Bagaimana respon pedagang terhadap tawaran bank konvensional, Bagaimana ketersediaan lembagan keuangan syariah yang menopang permodalan pedagang pasar, Bagaimana perkembangan pasar syariah beberapa tahun terakhir, Bagaimana penerapan teknologi keuangan syariah (ATM) dan Bagaimana ketersediaan Internet/Wifi di pasar syariah. Untuk lebih jelasnya skor masing masing factor ancaman dapat dilihat pada table berikut:

Tabel 4: Faktor Ancaman

\begin{tabular}{|c|l|c|c|c|}
\hline Ancaman & \multicolumn{1}{|c|}{ Keterangan } & Nilai & Bobot & N x B \\
\hline 1 & $\begin{array}{l}\text { Bagaimana tawaran pinjaman perbankan } \\
\text { konvensional pada pedagang pasar syariah }\end{array}$ & 2,01 & 0,17 & 0,3417 \\
\hline 2 & $\begin{array}{l}\text { Bagaimana respon pedagang terhadap } \\
\text { tawaran bank konvensional }\end{array}$ & 3 & 0,15 & 0,45 \\
\hline 3 & $\begin{array}{l}\text { Bagaimana ketersediaan lembagan } \\
\text { keuangan syariah yang menopang } \\
\text { permodalan pedagang pasar }\end{array}$ & 2,01 & 0,05 & 0,1005 \\
\hline 4 & $\begin{array}{l}\text { Bagaimana perkembangan pasar syariahn } \\
\text { beberapa tahun terakhir }\end{array}$ & 2,01 & 0,05 & 0,1005 \\
\hline 5 & $\begin{array}{l}\text { Bagaimana penerapan teknologi keuangan } \\
\text { syariah (ATM) }\end{array}$ & 3 & 0,05 & 0,2 \\
\hline 6 & $\begin{array}{l}\text { Bagaimana ketersediaan Internet/Wifi di } \\
\text { pasar syariah }\end{array}$ & 2 & 0,025 & 0,05 \\
\hline & \multicolumn{1}{|l|}{} & 1 & 1,2427 \\
\hline Sumber: Data Olahan 2019
\end{tabular}

Berdasarkan analisis IFAS dan EFAS di peroleh skor total yakni 1,03 sedangkan analisis EFAS 0,12 ini berarti kedua sor berada dalam posisi posis]tif. Tyakni berada pada posisi SO/ Strengh dan Opurtunities. Untuk leih lanjutnya dan jelasnya dapat dilihat pada diagram berikut ini :

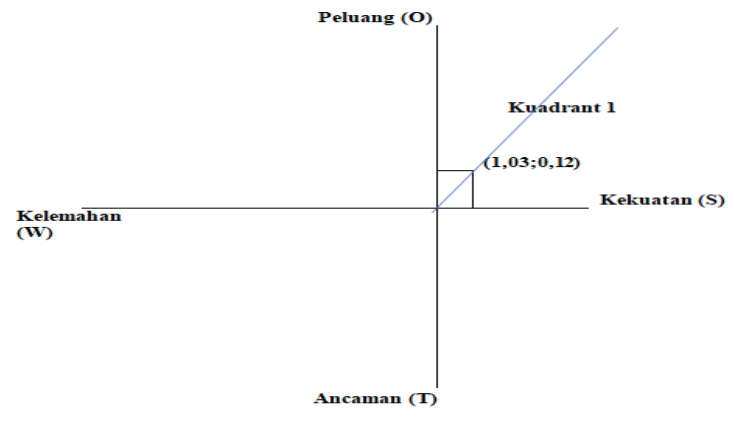

Diagram: SWOT Analisis 2019

\section{PEMBAHASAN}

Berdasarkan hasil penelitian yang berkaitan denagn kondisi factor internal dapat diketahui bahwa dari lima indicator kekuatan skor tertinggi terdapat pada Dari lima indicator kekuatan skor tertinggi terdapat pada Bagaimana Penerapan system syariah dipasar syariah, Bagaimana fungsi dewan syariah di pasar syariah dan Bagaimana ketaatan pedagang dalam menjalankan syariah dan dilanjutkan dengan Bagaimana pengetahuan pedagang 
terhadap transaksi syariah serta Bagaimana lembaga keuangan yang menopang permodalan pedagang pada pasar syariah. Apabila dilihat dari keseluruhan skor tertinggi yakni sebesar 1,836. Kemudian untuk factor terendah terdapat pada indicator Bagaimana lembaga keuangan yang menopang permodalan pedagang pada pasar syariah.

Selanjutnya pada factor kelemahan merupakan dimensi - dimensi yang terdapat pada Bagaimana penggunaan modal riba, Bagaimana penetapan harga oleh pedagang, Bagaimana akad yang digunakan dalam bertransksi dan Bagaiamna sanksi yang di terapkan.

Dari empat indicator kelemahan skor tertinggi terdapat pada Bagaimana akad yang digunakan dalam bertransaksi dan dilanjutkan dengan factor Bagaimana sanksi yang di terapkan. Apabila dilihat dari seluruh total skor yang mencapai angka rata - rata 0,8061 . Kemudian factor terendah terletak pada indicator bagaimana penggunaan modal riba dan kemudian di ikuti oleh Bagaimana penetapan harga oleh pedagang.

Selanjutnya berdasarkan hasil penelitian yang berkaitan tentang Strategi Penanggulangan Praktek Rentenir di Pasar Syariah Ulul Albab : pertama tama yang dilakukan yakni melakukan analisis factor eksternal (EFAS) internal factor analisis yang terdiri dari factor Peluang dan Ancaman yang dimiliki oleh pengelola/dewan syariah pasar di pasar syariah ulul albab.

Pada factor peluang yang merupakan dimensi - dimensi yang terdapat pada Bagaimana dukungan pemerintah terhadap keberadaan pasar syariah, Bagaimana respon masyarakat terhadap keberadaan pasar syariah, Bagaimana sikap dan kebijakkan pemerintah dalam mengembangkan pasar syariah, Bagaimana kondisi lingkungandisekitar pasar syariah dan Bagaimana keunggulan pasar syariah di bangdingkan pasar yang lain.

Sedangkan dari factor eksternal Dari lima indicator peluang skor tertinggi terdapat pada Bagaimana dukungan pemerintah terhadap keberadaan pasar syariah,
Bagaimana respon masyarakat terhadap keberadaan pasar syariah, dan Bagaimana keunggulan pasar syariah di bangdingkan pasar yang lain. Apabila dilihat dari keseluruhan skor di dapatkan skor rata rata yakni sebesar 1,36105. Kemudian factor terendah terletak pada indicator Bagaimana sikap dan kebijakkan pemerintah dalam mengembangkan pasar syariah dan Bagaimana kondisi lingkungandisekitar pasar syariah.

Selanjutnya pada factor ancaman yang merupakan dimensi - dimensi yang terdapatkan pada Bagaimana tawaran pinjaman perbankan konvensional pada pedagang pasar syariah, Bagaimana respon pedagang terhadap tawaran bank konvensional, Bagaimana ketersediaan lembagan keuangan syariah yang menopang permodalan pedagang pasar, Bagaimana perkembangan pasar syariah beberapa tahun terakhir, Bagaimana penerapan teknologi keuangan syariah (ATM) dan Bagaimana ketersediaan Internet/Wifi di pasar syariah.

Dari kedua faktor tersebut dan dari diagram tersebut dapat diketahui posisi fungsi dewan syariah di pasar syariah di pasar syariah ulul albab pada posisi SO yang berarti mendukung strategi Agredsif yakni dengan menggunakan kekuatan untuk menangkap peluang yang di miliki oleh pasar syariah ulul albab. Beberapa kebijakkan yang dapat diambil dengan menerapkan strategi Agresif.

Hal ini sejalan dengan Gunawan, R. D., Suryono, R. R., \& Purwanto, I. (2010). Kuadaran 1, merupakan situasi yang sangat menguntungkan, organisasi yang berada di kuadran tersebut memiliki peluang dan kekuatan sehingga dapat memanfaatkan peluang yang ada. Strategi yang harus diterapkan dalam kondisi ini adalah mendukung kebijakan pertumbuhan yang agresif. 


\section{SIMPULAN}

Berdasarkan hasil penelitian dapat ditarik beberapa kesimpulan antara lain yakni: Bahwasannya pada factor Internal (IFAS) kekuatan yang di miliki diketahui yang tertinggi yakni Penerapan system syariah dipasar syariah $(0,6)$ dan yang terendah yakni pada lembaga keuangan yang menopang permodalan pedagang pada pasar syariah $(0,22)$. Pada factor kelemahan pada pasar syariah ulul albab yakni yang tertinggi yakni akad yang digunakan dalam bertransksi yakni dengan skor 90,3) dan yang terendah yakni penggunaan modal riba $(0,1177)$.

Sementara pada factor Ekternal (EFAS) Peluang yang dimilki bahwasannya diketahui yang tertinggi yakni dukungan pemerintah terhadap keberadaan pasar syariah $(0,4788)$ dan yang terendah yakni sikap dan kebijakkan pemerintah dalam mengembangkan pasar syariah dengan skor $(0,133)$. Selanjutnya pada factor Ancaman pasar syariah ulul albab yakni yang teringgi yakni respon pedagang terhadap tawaran bank konvensional yakni dengan skor $(0,45)$ dan yang terendah yakni pada ketersediaan Internet/Wifi di pasar syariah dengan angka skor $(0,05)$.

Strategi agresif pada penanggulan praktek rentenir pada pedagang pasar syariah ulul albab dapat dilakukan dengan menggunakan strategi SO yakni dengan memanfaatkan kekuatan yang dimiliki yakni pasar syariah itu sendiri untuk menangkap peluang yang ada dan menggunakan Penerapan system syariah dipasar syariah untuk mendukung agar penerapan praktek rentenir itu sendiri bisa di akhiri dan segera untuk membentuk/mendirikan lembaga keuangan syariah/ yakni BMT (Baitul mall wa tan will) /koperasi syariah.

\section{DAFTAR RUJUKAN}

Awaluddin, M. (2017). Pengaruh Kepribadian Entrepreneushipislam Dan Akses Informasi Terhadap Strategi Bisnis Dan Kinerja Bisnis Usaha Kecil Di Kota Makassar. Iqtisaduna, 3(1).

Cahyani, E. S. dan P. D. (2016). Strategi Mempersempit Ruang Gerak Rentenir Melalui Kelompok Masyarakat Berbasis Modal Sosial (Studi Kasus Di Kampung Rahayu, Purwokerto). ISLAMADINA, XVII(2), 57-70.

digilib.uinsby.ac.id. (n.d.). Strategi Bmt Dan Praktik Rentenir Dalam Perspektif Ekonomi Islam, 21-50.

FAHMI, H. dan R. (2018). Pembiayaan Permodalan Ideal Dalam Mengatasi Praktik Rentenir. Jebi (Jurnal Ekonomi Dan Bisnis Islam), 3(1).

Gunawan, R. D., Suryono, R. R., \& Purwanto, I. (2010). Analisa Perubahan Manajemen Dalam Implementasi Si/ti Pada Perguruan Tinggi ABC. Jurnal Fakultas Hukum UII.

Hidayah, N. N. (2018). Infak sebagai Program Pengurangan Ketergantungan Masyarakat terhadap Rentenir (Studi Kasus pada BAZNAS Kabupaten Ngawi). Az Zarqa', 10(1).

Hijriah, H. Y. (2016). Spiritualitas Islam dalam Kewirausahaan. TSAQAFAH, Jurnal Peradaban Islam, 12(4), 187208.

https://www.kompasiana.com/nurdinmuha $\mathrm{mmad} / 55007 \mathrm{e} 03813311255 \mathrm{efa} 7 \mathrm{a} 47 / \mathrm{str}$ ategi-bisnis-nabi-muhammad-saw

https://www.iaeipusat.org/memberpost/ekonomisyariah/strategi-bisnis-syariah- 
berbasis-paradigmatik-quranik-dansirah-nubuwwah?language $=\mathrm{id}$

https://tafsirq.com/topik/An+nisa+ayat+29

Mujaddidi, A. S. (2017). Peran Strategis Bayt Al-Mal Wa Al-Tamwil Dalam Mengatasi Praktek Rentenir : Studi Bmt Nu Jawa Timur.

Oleh:, S., \& Khairi, M. (2018). Dampak Pinjaman Rentenir Terhadap Pendapatan Pedagang Pasar Tradsional Di Pasar Pagi Pulo Brayan Bengkel. Skripsi.

sabirin dan dini ayuning. (2017). Islamic Micro Finance Melati: Upaya Penguatan Permodalan bagi Pedagang Pasar Tradisional. Economica: Jurnal Ekonomi Islam, 8, 27-53.

SIBORO, I. K. (2015). Rentenir (Analisis Terhadap Fungsi Pinjaman Berbunga Dalam Masyarakat Rokan Hilir Kecamatan Bagan Sinembah Desa Bagan Batu ) Ilas Korwadi Siboro. Jom Fisip $V, 2$.

Surahma Asti Mulasari, Ana Nur Fatihah, A. S. (2018). Upaya Penanggulangan Rentenir Oleh Kuliah Kerja Nyata Universitas Ahmad Dahlan Di Nglegi, Patuk, Gunungkidul. Jurnal Pemberdayaan: Publikasi Hasil Pengabdian Kepada Masyarakat, 2(3), 479-486.

Syafrini, D. (2014). NELAYAN VS RENTENIR Studi Ketergantungan Nelayan terhadap Rentenir pada Masyarakat Pesisir. Jurnal Ilmu Sosial Mamangan, 1(2), 54-67.

Tunerah. (2015). Pengaruh Jasa Kredit Rentenir Terhadap Tingkat Kesejahteraan Masyarakat ( Studi Kasus Desa Karanganyar Kec. Kandanghaur Kab. Indramayu ). Skripsi. 